\title{
Effects of soft corals on scleractinian coral recruitment. I: Directional allelopathy and inhibition of settlement
}

\author{
Mauro Maida ${ }^{1, *}$, Paul W. Sammarco ${ }^{2}$, John C. Coll ${ }^{3, * *}$ \\ 'Department of Molecular Sciences, James Cook University of North Queensland, Townsville, Queensland 4811, Australia \\ ${ }^{2}$ Chancellory, Central Queensland University, Rockhampton, Queensland 4702, Australia \\ ${ }^{3}$ Louisiana Universities Marine Consortium, 8124 Hwy 56, Chauvin, Louisiana 70344, USA
}

\begin{abstract}
Experiments were performed on the Great Barrier Reef, at Orpheus Island $\left(18^{\circ} 40^{\prime} \mathrm{S}\right.$, $\left.145^{\circ} 30^{\prime} \mathrm{E}\right)$ and Lizard Island $\left(14^{\circ} 41^{\prime} \mathrm{S}, 145^{\circ} 28^{\circ} \mathrm{E}\right)$, Australia, to examine allelopathic effects of soft corals on the larval recruitment of scleractinian corals. Ceramic tiles were used as settlement plates and arranged around the soft corals Sinularia flexibilis (Quoy \& Gaimard) and Sarcophyton glaucum (Quoy \& Gaimard), serving as treatments. One control consisted of stacks of settlement plates uninfluenced by any organism, while a second control had settlement stacks surrounding a scleractinian coral to control for depletion of larvae via feeding. Coral spat recruitment was approximately 7 times higher at Lizard Island (7032) than at Orpheus Island (1038). The pattern of coral recruitment and relative abundances of coral recruits around the controls and soft corals, however, was similar at the 2 sites. The average density of coral spat was always significantly less around the soft corals than the controls, indicating that soft corals at each experimental site inhibited scleractinian coral recruitment. Coral recruitment levels were very similar for the 2 control treatments. Coral spat were asymmetrically distributed around the soft corals, and the distribution varied significantly with respect to the distance from the soft coral and the direction of the prevailing current at both Orpheus and Lizard Island. There was a significant negative correlation between coral spat density and current direction under both soft coral treatments and at both sites. No such response was observed in the controls. In a second experiment, scleractinian coral spat were exposed to settlement plates impregnated with the extract of S. flexibilis and control plates. Settlement only occurred on the untreated controls.
\end{abstract}

KEY WORDS: Alcyonacean · Scleractinian - Allelopathy · Directional effect - Coral settlement · Inhibition

\section{INTRODUCTION}

Alcyonacean soft corals produce a range of secondary metabolites, principally terpenoids (Tursch et al. 1978, Sammarco \& Coll 1988, Faulkner 1991, Coll 1992). Several ecological roles have been attributed to these compounds, including defense against predation (Coll et al. 1982b, La Barre et al. 1986b, Wylie \& Paul

\footnotetext{
- Present address: Department of Oceanography, Faculty of Science, Federal University of Pernambuco, Recife, CEP 55578.000 , Brazil

- Addressee for correspondence: Dr J. C. Coll, Chancellory, Central Queensland University, Rockhampton, Queensland 4702, Australia
}

1989, see also Van Alstyne \& Paul 1992, Harvell et al. 1993), competition for space (Sammarco et al. 1983, La Barre et al. 1986a, Dai 1990), gamete protection and sperm attraction in reproduction (Bowden et al. 1985, Coll \& Miller 1992), and antifouling (Tursch et al. 1978 Bakus et al. 1986, Coll et al. 1987).

Certain species of alcyonaceans release terpenoid toxins (Coll et al. 1982a), which act as allelopathic agents in competitive interactions with nearby scleractinian corals (Sammarco et al. 1983). Coll \& Sammarco (1983) demonstrated experimentally that some secondary metabolites cause tissue necrosis and mortality in scleractinian corals in the laboratory and field (Sammarco et al. 1983). To date, however, all studies of chemically mediated interactions between alcyona. 
cean and scleractinian corals have focused on adult colonies; none have focused on allelopathic effects on settlement success of scleractinian corals.

There have been numerous studies on the Great Barrier Reef on the settlement of scleractinian corals including spawning (Harrison et al. 1984, Babcock et al. 1986, Andrews et al, 1988), larval dispersal and recruitment (Sammarco \& Andrews 1988, 1989, Sammarco 1991, 1994), spatial and temporal variability in settlement (Sammarco 1983, Fitzhardinge 1985, Harriott 1985, Wallace 1985, Babcock 1988), postsettlement mortality and juvenile growth (Babcock \& Heyward 1986, Babcock 1988, Fitzhardinge 1988), and microhabitat preferences for settlement by coral larvae (Carleton \& Sammarco 1987, Harriott \& Fisk 1987). For related work from the Caribbean, Hawaii, and the Red Sea, see Vine (1974), Birkeland (1977), Bak \& Engel (1979), Rinkevich \& Loya (1979), Sammarco (1980, 1982), Hughes (1985), Hughes \& Jackson (1985), Shlesinger \& Loya (1985), Hodgson (1990) and Szmant (1991). Few studies have considered the possibility of chemical mediation in the settlement of corals (Morse \& Morse 1993, Pawlik 1992).

In a preliminary experiment (Maida et al. 1995), the soft coral Sinularia flexibilis significantly inhibited the recruitment of scleractinian coral spat on nearby substrata. This effect was most intense at positions downcurrent from the soft coral. This inhibition of coral settlement may have been the result of the allelopathic effects of S. flexibilis, or of soft coral feeding on the scleractinian coral larvae. Here we attempt to distinguish between these possibilities by comparing recruitment on plates placed around a planktivorous scleractinan coral that does not produce toxic secondary metabolites. In a second experiment, extracts of $S$. flexibilis were used to determine whether they inhibit scleractinian coral settlement.

Here we demonstrate that soft corals do affect the success of settlement in scleractinian corals.

\section{MATERIALS AND METHODS}

Field experiments. The experiment was performed at 2 sites, Orpheus Island $\left(18^{\circ} 40^{\prime} \mathrm{S}, 145^{\circ} 30^{\prime} \mathrm{E}\right)$ and Lizard Island (14\% $\left.41^{\prime} \mathrm{S}, 145^{\circ} 28^{\prime} \mathrm{E}\right)$, Great Barrier Reef, Australia. At Orpheus Island, the experiment was performed on the southern fringing reef of Pioneer Bay, beginning in early October 1990. At Lizard Island, the experiment was placed on the western fringing reef of Palfrey Island during early November 1990

At each site, the experiment comprised a set of 4 square galvanised steel grids, with sides $1.8 \mathrm{~m}$ in length, mounted $40 \mathrm{~cm}$ above the bottom at a mean depth of $4 \mathrm{~m}$ on the edge of a fringing reef. An organ- ism (or small current meter; see Maida et al. 1993) was placed at the centre of each grid, with stacks of settlement plates radiating from the centre. The grids were positioned so that each was subjected to the same physical (e.g. depth, current) and biological (e.g. planktonic, demersal, sedimentary) conditions.

Unglazed sides of ceramic tiles $(15 \times 15 \mathrm{~cm})$, which have been used in studies of coral settlement on the Great Barrier Reef (Harriott \& Fisk 1987, Fisk \& Harriott 1990), served as settlement substrata. Stacks of 5 tiles were prepared by centre-drilling, mounting on stainless steel bolts, and separating the unglazed surfaces by $12 \mathrm{~mm}$ plastic spacers (Fig. 1a). A gap of $12 \mathrm{~mm}$ (cf. 3 mm; Harriott \& Fisk 1987) reduced the effects of predators and grazers on the settlement substrata while permitting the free flow of water through the gaps and allowing light to penetrate between the plates (see Maida et al. 1994).

Three of the settlement stacks, separated by $10 \mathrm{~cm}$, were bolted to a PVC sheet $(15 \times 65 \mathrm{~cm}$; Fig. 1b). Eight PVC sheets with attached stacks were affixed to each of the 4 steel grids in a radial pattern from the centre of the grid to the 8 main directions of the compass (i.e. $N$, NE, E, SE, S, SW, W and NW; Fig. 2). Each PVC sheet (with settlement stacks) was attached to its steel grid, $5 \mathrm{~cm}$ from the margin of the coral, creating sample distances of 5,30 and $55 \mathrm{~cm}$ from the organism (Fig. 2).

The settlement plates are designed only to be replicates of distance within a direction from the soft coral (or control). Nothing more is implied or interpreted from them. The settlement plates are true replicates of distance and direction because of the settlement behavior of coral larvae and their scale of perception. In the terms of Levins (1968), coral planulae are coarse-grained organisms. They do not possess focusing eyes or strong swimming apparatus, and are only

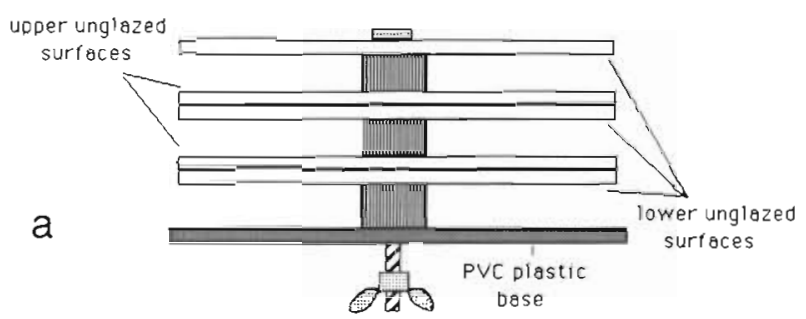

Fig. 1. Schematic diagram of the settlement plate units. (a) Settlement stack containing 3 unglazed lower surfaces and 2 unglazed upper surfaces mounted via a central bolt onto a PVC base; (b) 3 stacks of 5 settlement tiles, $10 \mathrm{~cm}$ apart from each other on a PVC sheet

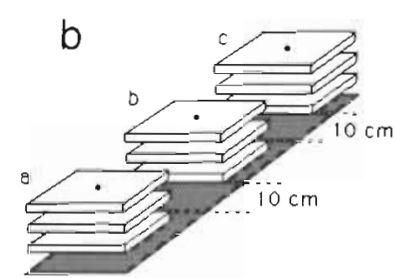




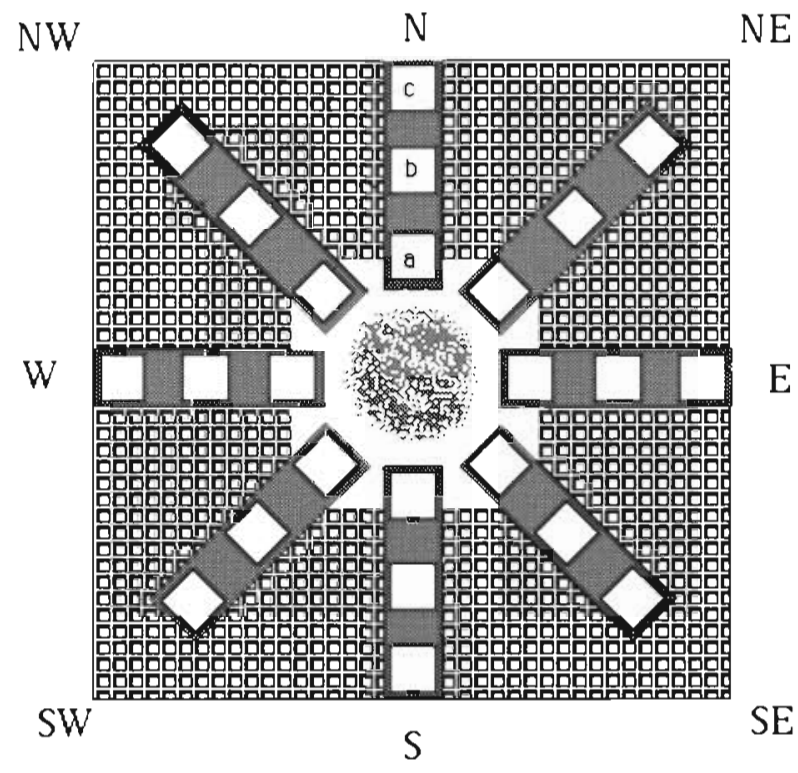

Fig. 2. Schematic representation of 1 grid showing the arrays of settlement plates mounted radially, starting $5 \mathrm{~cm}$ from the organism at the centre of the steel grid

500 to $1200 \mu \mathrm{m}$ in length. This limits them to perceiving only a small portion of their total environment, and they tactilely respond only to their immediate surroundings within a distance of perhaps several $\mathrm{mm}$, being unaware of the presence of other settlement substrata, which may be only $10 \mathrm{~mm}$ away. This concept has been discussed in greater detail by Sammarco (1994).

The experiment consisted of 2 treatments and 2 controls at each site. Treatment 1 was an array of settlement plates which was placed around a large colony of the soft coral Sinularia flexibilis (Quoy \& Gaimard, 1833) positioned in the centre of a steel grid. This treatment was designed to evaluate the directional effects of $S$. flexibilis on scleractinian coral recruitment as observed in the previous experiment (Maida et al. 1995). Treatment 2 was an array which was placed around a large colony of the soft coral Sarcophyton glaucum (Quoy \& Gaimard, 1833), another soft coral observed to cause necrosis in nearby scleractinian corals (Coll et al. 1982a, Sammarco et al. 1983).

Control 1 was represented by a grid and associated stack array which bore no organism at its centre, to control for recruitment of scleractinian corals in the absence of neighbouring organisms which might influence larval settlement. The current direction meter was positioned at the centre of this grid. Control 2 was represented by an array placed around a large scleractinian coral colony, providing data on coral settlement around a planktivorous organism which does not produce toxic secondary metabolites. The scleractinian coral used in the experiment at Orpheus Island was
Porites cylindrica (Dana, 1846), and at Lizard Island was Seriatopora hystrix (Dana, 1846). These corals were chosen because they had comparable polyp size and colony size, shape, and disposition to the soft corals used in the experiment.

The experiments were initiated $4 \mathrm{wk}$ prior to the annual peak of coral spawning for the respective regions (Harrison et al. 1984, Willis et al. 1985, Babcock et al. 1986). After 4 mo, 15 (of 288) settlement plates were analysed for settlement, and it was found that $>95 \%$ of recruitment at either site occurred on the lower unglazed surfaces ( 3 surfaces out of 5 per stack; see Fig. 1a; see also Maida 1993, Maida et al. 1994). After 9 mo, all settlement stacks were collected, held in flow-through seawater tanks and disassembled. The settlement plates were placed in a perspex tray filled with seawater and analysed in vivo under a dissecting microscope. In order to facilitate visual processing of the settlement plates, larger pieces of branching and filamentous algae were removed with fine dissecting forceps and the plates were washed clear of sediment with flowing seawater. Coral spat recruits were assessed for density (number per plate, $225 \mathrm{~cm}^{2}$ ) on each of the lower unglazed settlement surfaces (288 plates per site). Recruitment here is defined as settlement followed by deposition of a recognisable skeleton, irrespective of whether or not the spat were alive at the time of the analysis (sensu Wallace 1985).

Laboratory experiment. Preparation of settlement tiles: Samples of Sinularia flexibilis were collected from Lizard Island, frozen at $-20^{\circ} \mathrm{C}$ and freeze-dried. The freeze-dried coral tissue $(236 \mathrm{~g})$ was extracted with dichloromethane (DCM, $10 \mathrm{ml} \mathrm{g}^{-1}$ dry weight of tissue) by soaking the ground tissue in a sealed vial for 2 periods of $24 \mathrm{~h}$ and decanting the solvent from the sample after each extraction. The combined extract was evaporated to dryness using a rotary evaporator.

Ceramic tiles were used as settlement substrata $(7.5 \times 7.5 \mathrm{~cm})$. Twenty-five treatment tiles were impregnated by soaking the tiles in a solution containing $10 \mathrm{~g}$ of Sinularia flexibilis extract dissolved in DCM (1 1). Twenty-one control tiles were soaked in DCM only. Four of the treatment tiles were kept for later extraction and estimation of the amount of extract incorporated.

Recruitment choice study: Control and treatment tiles were placed on the bottom of 7 large plastic containers with meshed side windows ( $250 \mu \mathrm{m}$ mesh). The 7 containers were placed inside 7 seawater aquaria with continuous water flow. The water levels of the aquaria were adjusted to just expose the top of the plastic containers, in order to permit a water flow through the meshed windows and to avoid overflow and loss of larvae. The experiment was performed under natural photoperiod conditions. 
The experimental design utilized 2 aquaria containing 6 control tiles in each, 2 aquaria with 6 treatment (coated with extract) tiles in each, and 3 aquaria with 3 treatment and 3 control tiles in each.

The experiment was carried out with coral planulae collected in November 1992 at Orpheus Island. Details of the methods of fertilization and larval rearing are described in Babcock \& Heyward (1986). In the beginning of the experiment, approximately 500 coral larvae ( $4 \mathrm{~d}$ old) were transferred via pipette into each of the plastic tanks containing the settlement tiles. After $10 \mathrm{~d}$, the settlement tiles were retrieved from the tanks and the coral spat were counted using a dissecting microscope.

Data analyses: The field experiments followed a Model I 3-way factorial analysis of variance (ANOVA) design. The density of coral spat was assessed under the influence of the 3 factors: (1) type of organism at the center of the grid (Sinularia flexibilis, Sarcophyton glaucum, scleractinian coral and blank control); (2) directional disposition of the settlement plates relative to compass direction; and (3) distance of the settlement plates from the organisms.

Prior to analysis, the data were tested for normality and homoscedasticity. When necessary, data were transformed to square root $(y+0.5)$ for purposes of normalization (see Sakal \& Rohlf 1981, Zar 1984).

Allelopathic responses (Williamson \& Richardson 1988) were estimated using an index which measures the treatment responses ( $T$ ) in relation to their control responses (C). The index, called the Response Index $(R I)$, is defined as follows: if $T \geq C$, then $R I=1-(C / T)$; and if $T<C$, then $R I=(T / C)-1$. To determine the allelopathic effect of soft corals on scleractinian coral recruitment, the treatment responses for the calculation of the indices were considered to be the number of coral spat in a given position around the soft coral (i.e. at a given distance and direction). The control responses were considered to be the number of coral spat in the same relative position (i.e. distance and direction), but around one of the controls. Negative RI values indicated inhibition of scleractinian coral settlement on the plates; positive values indicated stimulation of coral settlement. Each treatment was compared to each control using Wilcoxon's Sign Test (Sokal \& Rohlf 1981).

Local current direction data were collected using a small current direction meter (see Maida et al. 1993) which provided data on the number of hours during which the local currents flowed in each of 8 compass directions. The current meter remained submersed for $131 \mathrm{~d}$ at Orpheus Island and $160 \mathrm{~d}$ at Lizard Island.

The relative effect of the current-borne allelochemicals at each position around the organisms was estimated with a simple geometric model, assisted by com- puter graphics. We took into consideration the sizes of the corals, the grid, the distance, direction and size of settlement stacks, and the $45^{\circ}$ arc of a given current direction (e.g. for $N, N \pm 22.5^{\circ}$ ) and the time during which the toxins, released by the organism at the centre of the grid, were carried to each position under the influence of local currents. This approach yielded similar values for all equivalent positions along each directional axis because of the symmetry of the grid design.

We will illustrate by example. Consider the settlement stacks along the north-facing axis. All 3 stacks 5,30 , and $55 \mathrm{~cm}$ from the corals - will experience the full effect of a current from the south. When the current flows from the SW, exposure of the settlement stacks along the north-facing axis will change. This is because the size of the soft coral $(\sim 60 \mathrm{~cm})$ is large relative to that of the settlement stacks $(15 \mathrm{~cm})$; thus, the current will have the same potential allelopathic effect on the stack $5 \mathrm{~cm}$ distant from the soft coral, but not the stacks 30 or $55 \mathrm{~cm}$ away. In this case, the same applies to a current from the SE. At a distance of $30 \mathrm{~cm}$ from the coral, a current from the SW (and SE) will only affect the settlement racks on the north-facing axis for a certain proportion of the recorded flow, namely $37 \%$ of the flow derived from the SW and SE. At $55 \mathrm{~cm}$, this value drops to $11 \%$. A list of the estimated relative effects of currents from different directions on each position of the steel support grid is presented in Table 1 .

Limits of the experimental design. The results presented here build on those from a similar preliminary experiment. That experiment followed a random blocks design and was performed on Orpheus Island, one of the islands used here (Maida 1993, Maida et al. 1995). The results from that experiment are entirely consistent with the results reported in this paper. We were unable to utilize a random blocks design here, due to the number of person-hours required to process the many settlement plates needed, which would have doubled or tripled the size of the experiment. As a result, the island sites we used in this experiment Orpheus and Lizard Islands - had only 1 block of grids each. Despite the fact that these islands were approximately $600 \mathrm{~km}$ apart, the results were consistent between them, with relative densities of coral settlement between treatments being the same.

Although one could design an experiment to yield much more information, including an estimate of within-reef, intersite variability, this was not logistically possible here. We feel that the robustness and consistency between the results of 2 similar experiments performed at the same site on 2 different occasions, and between 2 experiments performed on widely separated islands at the same time, allow us to make strong inferences from the study. 
Table 1. Model used for the calculation of the rank of current effects per position of the settlement plates (directions and distances). Directions in the column of current effects represent the period during which the current was flowing in that direction (see text)

\begin{tabular}{|c|c|c|}
\hline Direction & Distance $(\mathrm{cm})$ & Current effect \\
\hline \multirow[t]{3}{*}{ North } & 5 & $N+N W+N E$ \\
\hline & 30 & $\mathrm{~N}+0.37 \mathrm{NW}+0.37 \mathrm{NE}$ \\
\hline & 55 & $\mathrm{~N}+0.12 \mathrm{NW}+0.12 \mathrm{NE}$ \\
\hline \multirow[t]{3}{*}{ Northeast } & 5 & $N E+N+E$ \\
\hline & 30 & $\mathrm{NE}+0.37 \mathrm{~N}+0.37 \mathrm{E}$ \\
\hline & 55 & $\mathrm{NE}+0.12 \mathrm{~N}+0.12 \mathrm{E}$ \\
\hline \multirow[t]{3}{*}{ East } & 5 & $E+N E+S E$ \\
\hline & 30 & $\mathrm{E}+0.37 \mathrm{NE}+0.37 \mathrm{SE}$ \\
\hline & 55 & $\mathrm{E}+0.12 \mathrm{NE}+0.12 \mathrm{SE}$ \\
\hline \multirow[t]{3}{*}{ Southeast } & 5 & $S E+E+S$ \\
\hline & 30 & $\mathrm{SE}+0.37 \mathrm{E}+0.37 \mathrm{~S}$ \\
\hline & 55 & $\mathrm{SE}+0.12 \mathrm{E}+0.12 \mathrm{~S}$ \\
\hline \multirow[t]{3}{*}{ South } & 5 & $\mathrm{~S}+\mathrm{SE}+\mathrm{SW}$ \\
\hline & 30 & $\mathrm{~S}+0.37 \mathrm{SE}+0.37 \mathrm{SW}$ \\
\hline & 55 & $\mathrm{~S}+0.12 \mathrm{SE}+0.12 \mathrm{SW}$ \\
\hline \multirow[t]{3}{*}{ Southwest } & 5 & $\mathrm{SW}+\mathrm{S}+\mathrm{W}$ \\
\hline & 30 & $S W+0.37 S+0.37 W$ \\
\hline & 55 & $\mathrm{SW}+0.12 \mathrm{~S}+0.12 \mathrm{~W}$ \\
\hline \multirow[t]{3}{*}{ West } & 5 & $W+S W+N W$ \\
\hline & 25 & $W+0.37 S W+0.37 N W$ \\
\hline & 50 & $W+0.12 S W+0.12 N W$ \\
\hline \multirow[t]{3}{*}{ Northwest } & 5 & $\mathrm{NW}+\mathrm{W}+\mathrm{N}$ \\
\hline & 30 & $\mathrm{NW}+0.37 \mathrm{~W}+0.37 \mathrm{~N}$ \\
\hline & 55 & $\mathrm{NW}+0.12 \mathrm{~W}+0.12 \mathrm{~N}$ \\
\hline
\end{tabular}

\section{RESULTS}

\section{Field experiments}

At Orpheus Island, a total of 1038 coral recruits were found on the lower surfaces of 288 settlement plates. The total number of coral spat found was: Sinularia flexibilis treatment $(\mathrm{S} 1)=226$, Sarcophyton glaucum treatment $(\mathrm{S} 2)=168$, Control $1(\mathrm{C} 1)=323$ and Porites cylindrica control $(\mathrm{C} 2)=321$. At Lizard Island a total of 7032 coral spat were found on the same number of settlement plates (lower surfaces) in the following numbers: $S$. flexibilis treatment $(\mathrm{S} 1)=1590, S$. glaucum treatment $(\mathrm{S} 2)=1457$, Control 1 (C1) $=1966$ and Seriatopora hystrix control (C2) $=2019$.

Although the number of coral spat that settled at Lizard Island was approximately 7 times higher than the number found at Orpheus Island, the overall pattern of coral recruitment around the different treatments (soft corals and controls) was similar at the 2 sites.

\section{Settlement density}

At both sites, the average density of coral spat varied significantly between soft corals and controls ( $p<$ 0.001 for both Orpheus and Lizard Islands, 3-way ANOVA). That is, both soft corals at both experimental sites inhibited scleractinian coral recruitment (Fig. 3a, b). Settlement plates under the influence of Sarcophyton glaucum had the lowest level of scleractinian coral recruitment.

Tukey's a posteriori Multiple Comparison of Means Test (Sokal \& Rohlf 1981) indicated that the levels of recruitment in the blank control (Control 1) were not significantly different from the levels associated with the scleractinian coral (Porites cylindrica at Orpheus Island, Seriatopora hystrix at Lizard Island, Control 2). Coral settlement was suppressed to comparable extents by Sinularia flexibilis or Sarcophyton glaucum (Table 2).

a

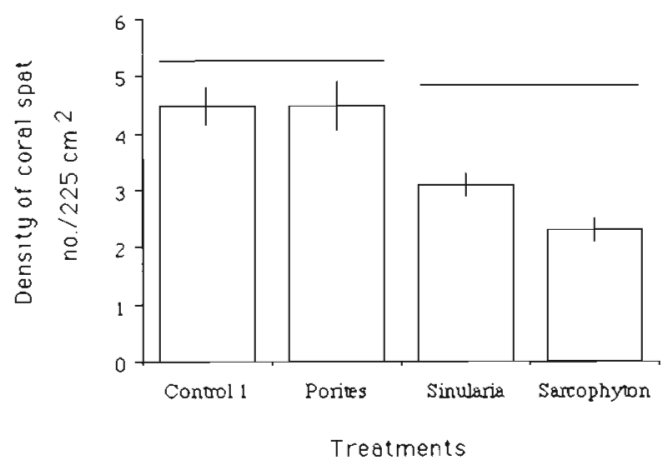

$\mathrm{b}$

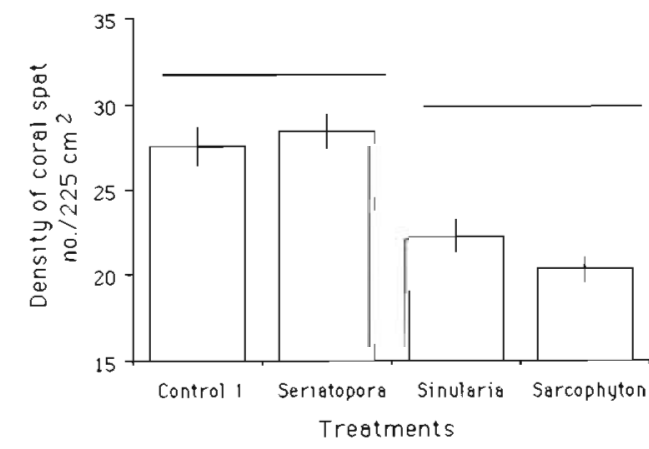

Fig. 3. (a) Overall density of scleractinian coral spat per treatment at Orpheus Island. Significant inhibition of coral recruitment on the settlement plates around both soft corals (Sinularia flexibilis and Sarcophyton glaucum), when comparared with the settlement plates around the controls (Control 1 and Porites cylindrica) (3-way ANOVA, $\mathrm{p}<0.001$ ). (b) Overall density of scleractinian coral spat per treatment at Lizard Island. Significant inhibition of coral recruitment on the settlement plates around soft corals (S. flexibilis and S. glaucum) compared with controls (Control 1 and Seriatopora hystrix, 3way ANOVA, $\mathrm{p}<0.001)$. Data were square-root transformed $(y+0.5)$ for purposes of normalization. Error bars represent 1 SE. Horizontal lines represent similarity between treatments given by Tukey's Test. $N=72$ in each case 
Table 2. Results of 3-way ANOVA for experiments at Orpheus Island and Lizard Island. "'Highly significant, "significant, ns: not significant. Treatments: presence of Sinulana flexibilis, presence of Sarcophyton glaucum, presence of scleractinian coral (Senatopera hystrix or Porites cylindrica, respectively), and absence of corals. Distances: $5,30,55 \mathrm{~cm}$ from the corals Directions: N, NE, E, SE, S, SW, W, NW

\begin{tabular}{|c|c|c|c|c|c|}
\hline Source & df & SS & MS & $F$-value & $p$-value \\
\hline \multicolumn{6}{|l|}{ Orpheus Island } \\
\hline Treatments & 3 & 15.980 & 5.927 & 17.284 & $<0.001 \cdots$ \\
\hline Distances & 2 & 4.270 & 2.135 & 6.967 & $<0.01 \cdots$ \\
\hline Directions & 7 & 15.867 & 2.267 & 7.397 & $<0.001 \cdots$ \\
\hline Treatment $\times$ Distances & 6 & 2.910 & 0.485 & 1.582 & $>0.1 \mathrm{~ns}$ \\
\hline Treatment $\times$ Directions & 21 & 8.336 & 0.697 & 1.295 & $>0.1 \mathrm{~ns}$ \\
\hline Distances $\times$ Directions & 14 & 6.533 & 0.467 & 1.523 & $>0.1 \mathrm{~ns}$ \\
\hline Treat. $\times$ Dist. $\times$ Dir & 42 & 11.030 & 0.263 & 0.857 & $>0.5 \mathrm{~ns}$ \\
\hline Residual & 192 & 58.838 & 0.306 & & \\
\hline \multicolumn{6}{|l|}{ Lizard Island } \\
\hline Treatments & 3 & 32.710 & 10.903 & 23.728 & $<0.001 \cdots$ \\
\hline Distances & 2 & 7.926 & 3.963 & 8.624 & $<0.001 \cdots$ \\
\hline Directions & 7 & 30.968 & 4.424 & 9.628 & $<0.001 \cdots$ \\
\hline Treatment $\times$ Distances & 6 & 8.099 & 1.350 & 2.937 & $<0.01 \cdots$ \\
\hline Treatment $\times$ Directions & 21 & 18.298 & 0.871 & 1.896 & $<0.05^{\circ}$ \\
\hline Distances $\times$ Directions & 14 & 6.585 & 0.470 & 1.024 & $>0.1 \mathrm{~ns}$ \\
\hline Treat. $\times$ Dist. $\times$ Dir & 42 & 28.629 & 0.682 & 1.483 & $<0.05^{\circ}$ \\
\hline Residual & 191 & 87.768 & 0.460 & & \\
\hline
\end{tabular}

\section{Allelopathic response index}

The allelopathic response index $(R I)$ illustrated the results well, indicating that both soft corals inhibit coral recruitment relative to the blank control (Sinularia flexibilis/Control 1, $p<0.001$, Wilcoxon Sign Test; Sarcophyton glaucum/Control 1, $p<0.0001)$. The same was true with respect to recruitment under the influence of the scleractinian coral (S. flexibilis/Porites cylindrica, $\mathrm{p}<$ 0.001; S. glaucum/P. cylindrica, $\mathrm{p}<0.0001$ ). The scleractinian coral $P$. cylindrica was not found to inhibit coral recruitment $(P$. cylindrica/Control 1 , $\mathrm{p}>0.5$, Fig. 4).

Fig. 4. Allelopathic Response Index for Orpheus Island data, calculated from the number of coral spat on each settlement plate around each soft coral (S1, Sinularia flexibilis; S2, Sarcophyton giaucum) and control (C1. blank control; C2, Porites cylindrica). For example, the first column of the graph marked S1C1 was calculated using the number of coral spat on settlement plate number 1 of the northerly set, occurring $5 \mathrm{~cm}$ from the soft coral S. flexibilis, and the number of coral spat on settlement plate number 1 of the same direction and distance from Control 1. See 'Materials and methods' for details of calculation. Data analyzed by the Binomal Sign Test, indicating whether the distribution of number of negative (inhlbition) and positive (stimulation) recrutment response indices was random. Probabilities presented in each graph. Both soft corals significantly inhibited coral recruitment, while the scleractinian coral $P$. cylindrica did not
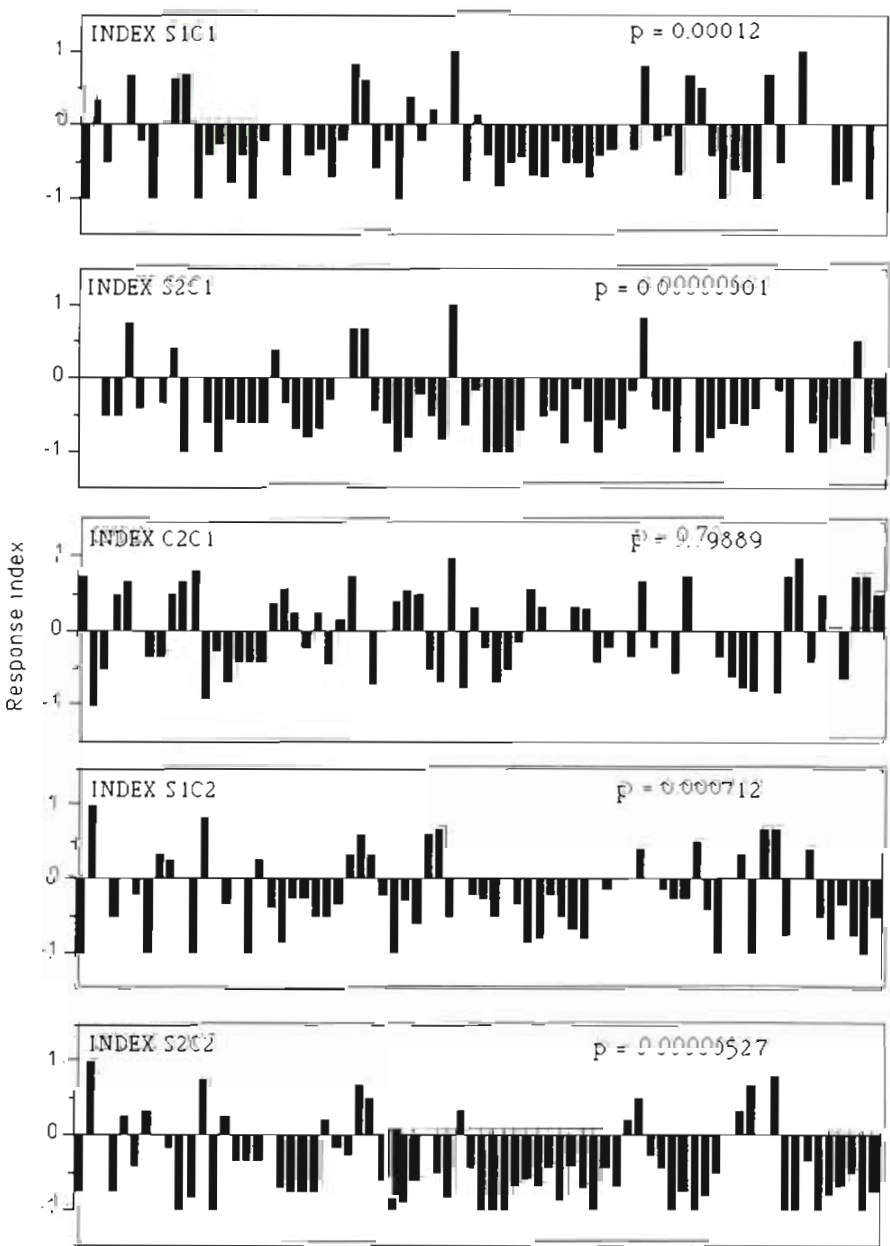


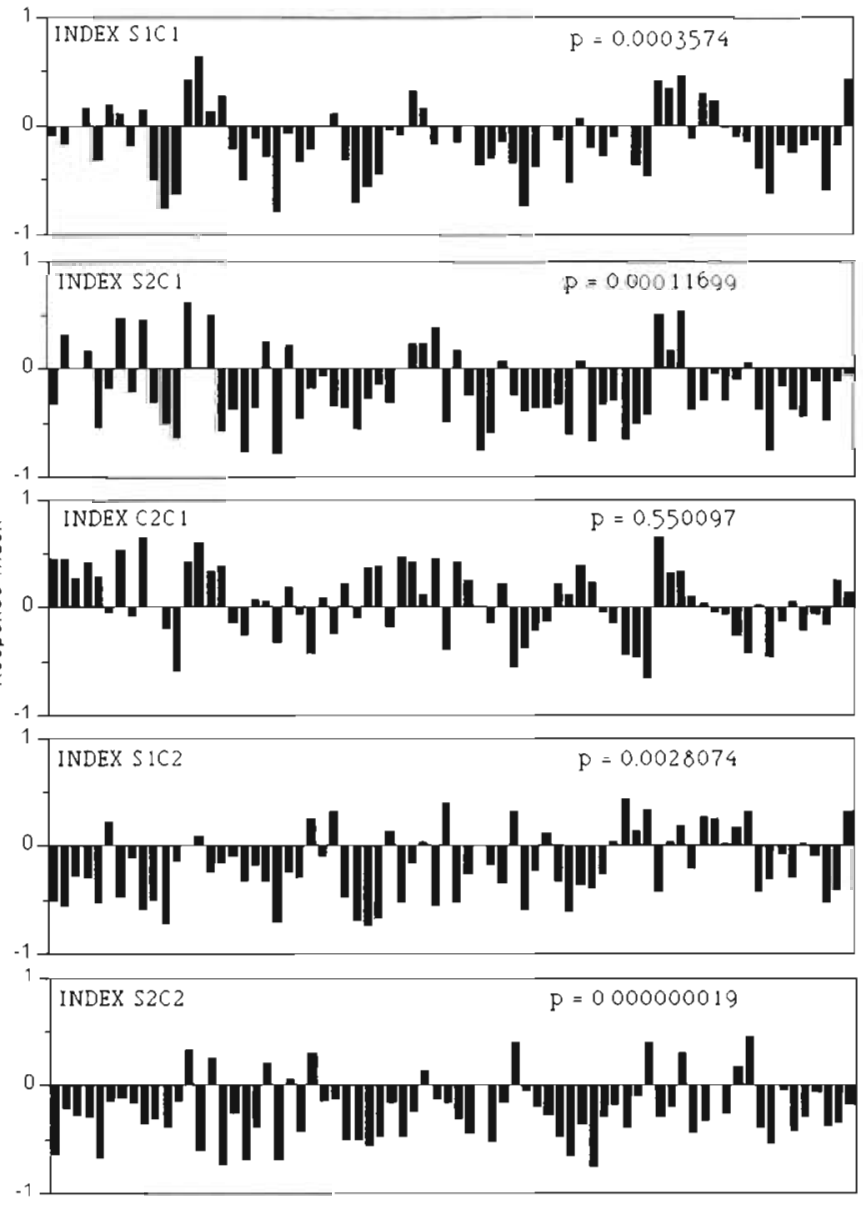

Fig. 5. Allelopathic Response Index for Lizard Island. See Fig. 4 for details. Probabilities of Binomial Sign Test presented in each graph. Both soft corals significantly inhibited coral recruitment, while the scleractinian coral Seriatopora hystrix did not

At Lizard Island, the index indicated that both soft corals inhibited scleractinian coral recruitment when compared with either Control 1 or Control 2: Sinularia flexibilis/Control 1, p $<0.001$, Wilcoxon Sign Test; Sarcophyton glaucum/Control 1, p < 0.001; S. flexibilis/Seriatopora hystrix, $\mathrm{p}<0.01$; S. glaucum/S. hystrix, $\mathrm{p}<0.0001$ ). The $S$. hystrix control (Control 2) had no significant effect on coral recruitment ( $S$. hystrix/Control 1, p > 0.5, Fig. 5 ).

Directional and distance effects on coral recruitment

Orpheus Island. Coral settlement was significantly different between distances ( $p<0.01,3$-way ANOVA) and between directions $(p<0.001)$ for the Orpheus Island experiment (Table 2). No significant higherorder interactions were found between any of the factors examined here $(p>0.1)$.
When the mean number of recruits per direction is compared between treatments and controls (Fig. 6), it may be seen that the presence of soft corals suppresses success of coral settlement. This was particularly evident in the $W$ and NW sectors around both soft corals (Sinularia flexibilis and Sarcophyton glaucum, Fig. 6).

The current data indicated that during the $131 \mathrm{~d}$ period of data collection, currents flowed towards the SW, W and NW for $58.5 \%$ of the time at Orpheus Island (Fig. 6). The lowest level of coral recruitment was thus observed downcurrent from both soft corals.

A plot of treatments versus distances clearly indicated that coral recruitment was greatly inhibited on the settlement plates $5 \mathrm{~cm}$ from the soft coral Sarcophyton glaucum. This was not observed in Sinularia flexi-

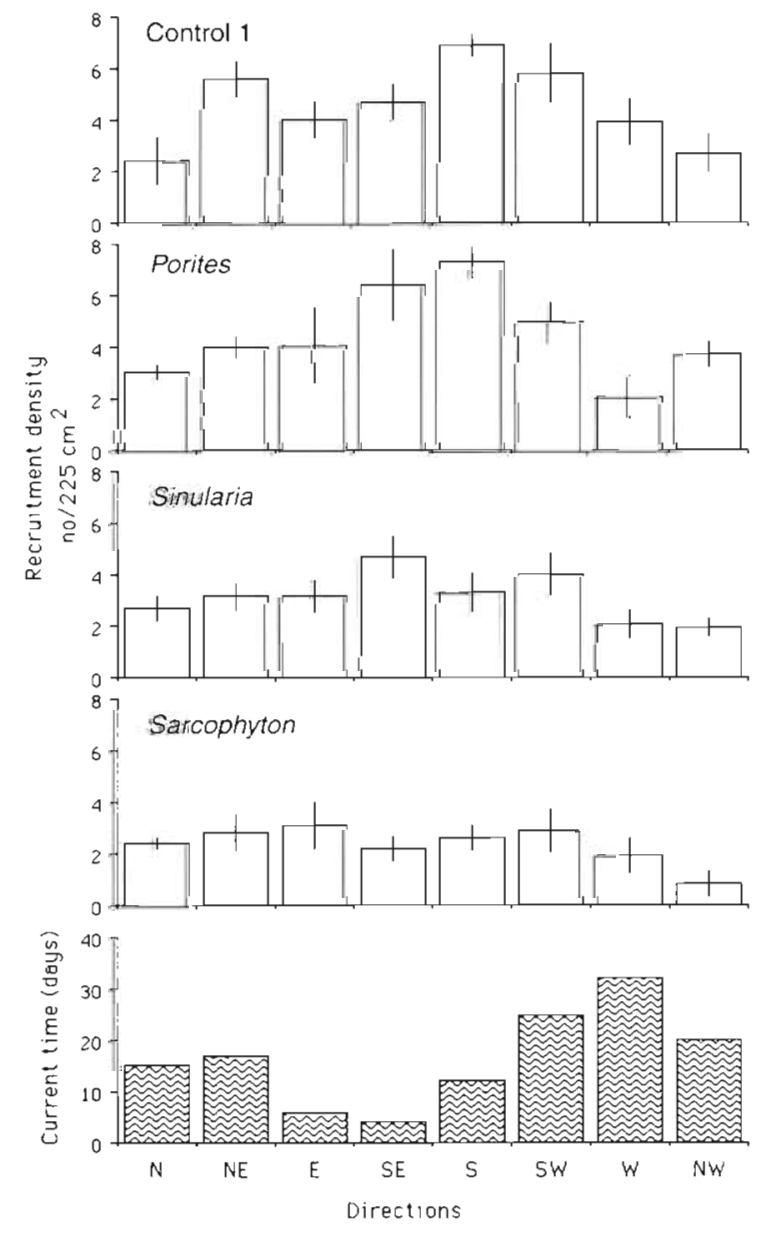

Fig. 6. Average density of coral spat by direction for the settlement plates around both treatments (Sinularia flexibilis and Sarcophyton glaucum) and controls (Control 1 and Porites cylindrica) at Orpheus Island. Significantly lower densities of scleractinian coral spat were observed on settlement plates downcurrent from the soft corals. Error bars represent $\mathrm{SE}$; $\mathrm{N}=9$ for each case. Current data derived from directional measurements at the study site over $131 \mathrm{~d}$ during the course of the experiment 


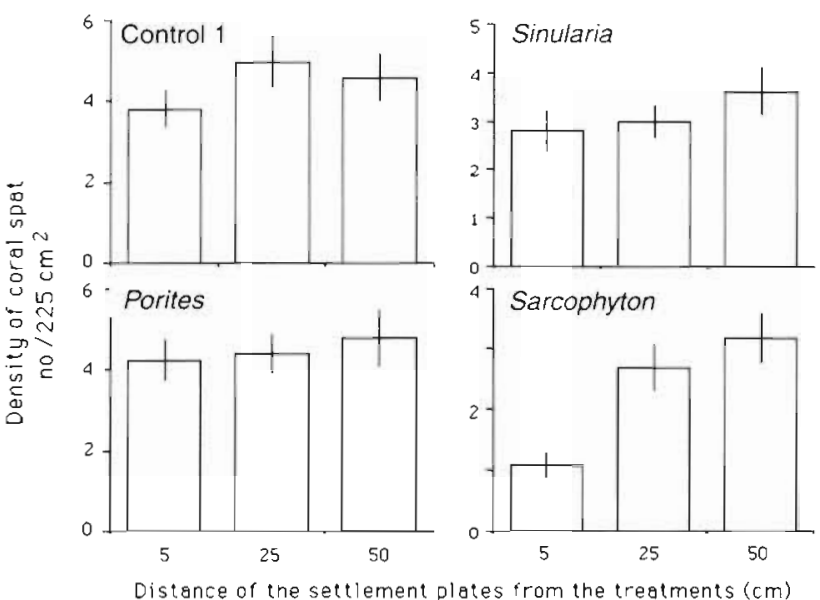

Fig. 7. Average density of coral spat by distance from the soft coral or treatment at Orpheus Island. Settlement plates $5 \mathrm{~cm}$ away from the soft coral Sarcophyton glaucum yielded the lowest level of coral recruitment. Error bars represent $\mathrm{SE}_{i}$ $\mathrm{N}=24$ in each case

bilis (Fig. 7). It is possible that recruitment variability was sufficiently high to mask this distance effect.

Lizard Island. There were significant differences in coral recruitment with respect to distances $(p<0.001$, 3 -way ANOVA) and directions $(p<0.001)$ at Lizard Island. There were significant higher-order interactions between treatments and distances $(p<0.001)$, treatment and directions $(\mathrm{p}<0.05)$, and treatments, distances and directions $(p<0.05)$ (Table 2). A plot of the mean number of coral recruits for the interaction between treatments and directions (Fig. 8) revealed that coral recruitment density was dependent upon the presence or absence of soft corals. The lowest densities of scleractinian coral spat were observed on the north sides of the soft corals.

The current data from Lizard Island showed that, during the measurement period $(160 \mathrm{~d})$, currents flowed towards N and NE for $50 \%$ of the time (Fig. 8). Currents at the study site appeared to be driven primarily by the predominant S-SE winds in the region.

Regarding distance effects, a plot of means of coral recruits for the interaction between treatments and distances clearly indicated that coral recruitment was strongly inhibited $5 \mathrm{~cm}$ from the soft coral Sinularia flexibilis, and to a lesser extent, from Sarcophyton glaucum (Fig. 9). There were no obvious distance effects on coral recruitment around the controls (Control 1 and Seriatopora hystrix).

\section{Effect of currents on coral recruitment}

When the amount of time during which current flowed in a given direction is compared with direc-
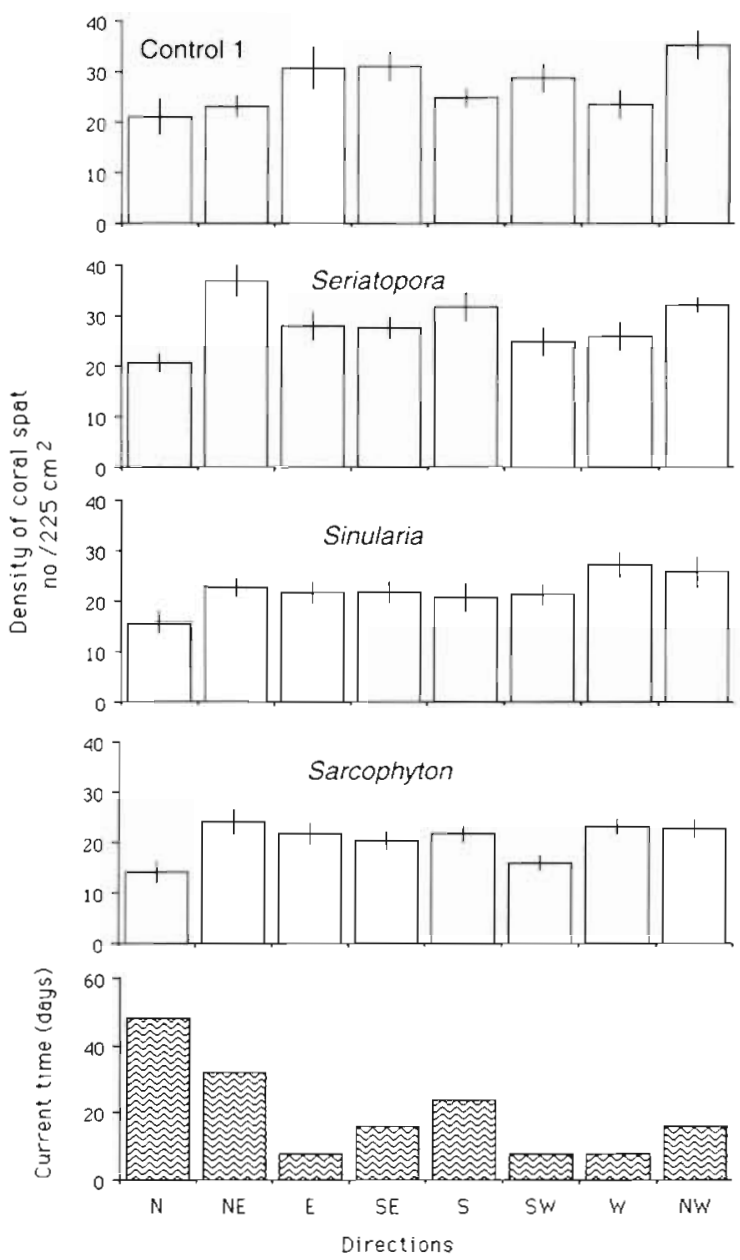

Fig. 8. Average density of coral spat on settlement plates by direction around the soft corals (Sinulana flexibilis and Sarcophyton glaucum) and around the controls (blank control and Seriatopora hystrix) at Lizard Island. Lowest densities of scleractinian coral spat were observed down-current from the soft corals (predominant current was north). Error bars represent $\mathrm{SE}_{\mathrm{i}} \mathrm{N}=9$ in each case. Current data derived from directional measurements at the study site over $1.60 \mathrm{~d}$ during the course of the experiment

tional coral recruitment at Orpheus Island, significant negative correlations become evident for both Sinularia flexibilis $(r=-0.509, \mathrm{p}<0.01$, Spearman Rank Correlation Test) and Sarcophyton glaucum ( $\mathrm{r}=$ $-0.604, p<0.01$ ). That is, the number of coral recruits at a given position around either soft coral decreased with the increased time during which current flowed towards that position. Similar analyses on the blank control data (Control 1), and the scleractinian coral control (Porites cylindrica, Control 2) revealed no such correlation $(r=0.230, p>0.1$, and $r=0.395, p>0.05$, respectively; Fig. 10).

Similar effects were abserved at Lizard Island. There were significant negative correlations between coral spat density and the time during which current flowed 


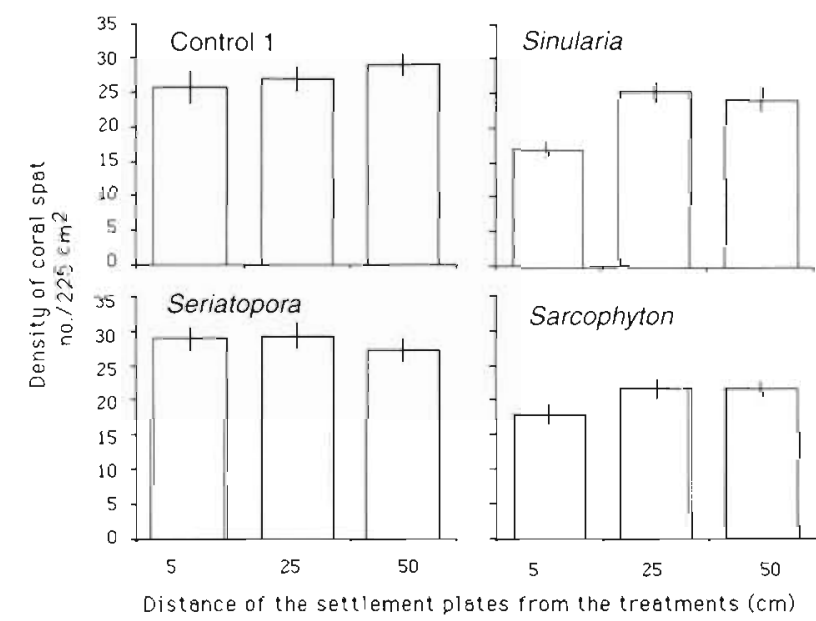

Fig. 9. Average density of coral spat in treatments by distance at Lizard Island. Settlement plates $5 \mathrm{~cm}$ from Sinularia flexibilis yielded lowest coral recruitment. Error bars represent SE; $N=24$ in each case
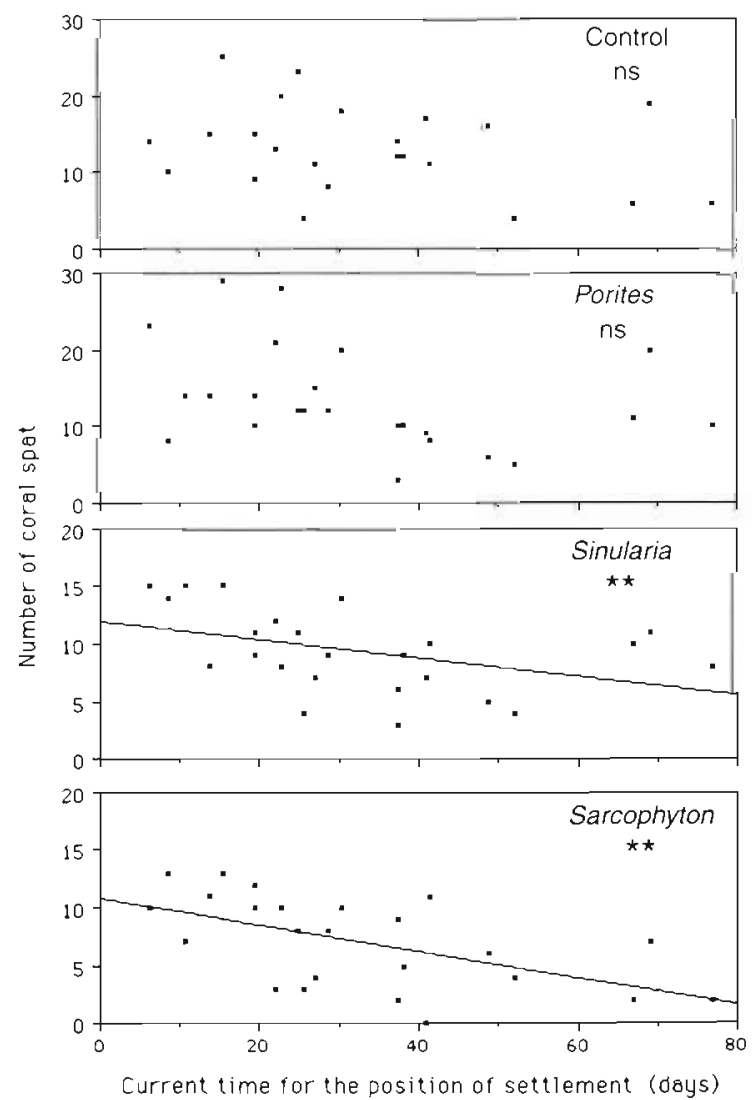

Fig. 10. Scattergram of coral spat around a treatment versus time during which current was flowing towards that position, at Orpheus Island. Significant negative correlation in the cases of Sinularia flexibilis $(r=-0.509, p<0.01$, Spearman Rank Correlation Analysis) and Sarcophyton glaucum ( $\mathrm{r}=$ $-0.604, p<0.01)$. No such correlation for Control $1(r=0.230$, $\mathrm{p}>0.1$ ) and Control 2 (Porites cylindrica, $\mathrm{r}=0.395, \mathrm{p}>0.05$ ).

"Highly significant; ns: not significant

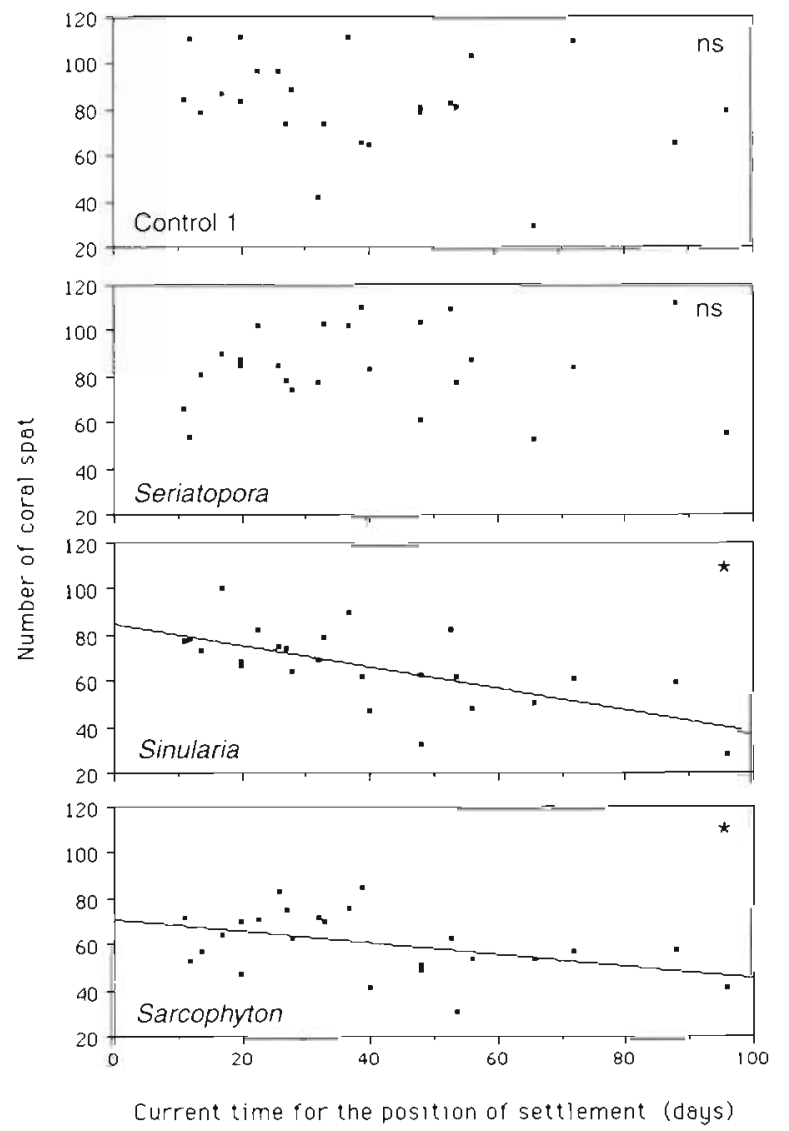

Fig. 11. Scattergram of coral spat around a treatment versus time during which current was flowing towards that position, at Lizard Island. Significant negative correlation in the cases of Sinularia flexibilis $(r=-0.416, p<0.05)$ and Sarcophytum glaucum $(\mathrm{r}=-0.455, \mathrm{p}<0.05$, Spearman Correlation Coefficient). No such correlation was observed for Control 1 ( $\mathrm{r}=$ $-0.343, \mathrm{p}>0.1$ ) or Control 2 (Seriatopora hystrix, $\mathrm{r}=-0.136$, $p>0.51 . \cdot$ Significant; ns: not significant

in a given direction in Sinularia flexibilis $(r=-0.416$, $\mathrm{p}<0.05$, Spearman Rank Correlation Test) and Sarcophytum glaucum $(\mathrm{r}=-0.455, \mathrm{p}<0.05)$. No such correlation was found in either the blank (Control 1) or the scleractinian coral control (Seriatopora hystrix, Control 2) $(r=-0.343, p>0.1$, and $r=-0.139, p>0.5$, respectively; Fig. 11).

\section{Laboratory experiments: settlement inhibition}

Extraction of the 4 treatment tiles revealed the adsorption of approximately $28 \mathrm{mg}( \pm 0.75 \mathrm{SE})$ of crude extract on each tile $\left(497 \mathrm{\mu g} \mathrm{cm}^{-2}\right)$.

Only 18 out of 3500 coral planulae settled on the plates. Of these 18 , all settled on the control plates; none were found on the plates treated with the Sinularia flexibilis extract. The success of coral settlement 
on control tiles versus extract tiles was not a random event (Wilcoxon Sign Test, $\mathrm{p}<0.001$ ).

\section{DISCUSSION}

The fact that the density of coral spat was lower at Orpheus Island than at Lizard Island is consistent with the general pattern observed for inshore and mid-shelf reefs (Sammarco 1983, 1985, 1987, 1991; see also Wallace 1985). Sammarco (1991) noted that lower levels of coral recruitment on inshore reefs appear to be a result of geographically specific selection factors. This included environmental characteristics associated with the inshore environment, such as higher sedimentation and more variable salinity, which suppress success of coral settlement.

The levels of coral recruitment at Orpheus Island observed in this experiment were similar to those observed in the preliminary experiment (Maida et al. 1995). At Lizard Island, however, overall recruitment densities were higher than those at Orpheus Island and those previously reported for Lizard Island (Harriott 1985). Recruitment occurred exclusively on the lower surfaces of the settlement plates at each site, as noted elsewhere (Maida et al. 1994; see also Sammarco 1983, 1987, Carleton \& Sammarco 1987).

Although the 2 sites differed in overall coral spat abundance, the ratios of coral spat densities between treatments and controls were generally the same. This indicated that soft corals are indeed capable of inhibiting scleractinian coral settlement on nearby substrates.

At both sites, the results indicated that the presence of the scleractinian corals (Porites cylindrica at Orpheus Island, Seriatopora hystrix at Lizard Island) did not influence coral recruitment. That is, coral recruitment density around the planktivorous scleractinian corals (Control 2) was not different from that in the absence of a planktivorous sessile organism (Control 1). This was observed at both study sites. These results suggest that the observed reduction of coral recruitment on the settlement plates around the soft corals was not caused by soft corals feeding upon scleractinian coral larvae.

The soft corals used here - Sinularia flexibilis and Sarcophyton glaucum - are known to contain toxic secondary metabolites (Coll et al. 1982b), to release them (Coll et al. 1982a), and cause mortality in scleractinian corals (Coll \& Sammarco 1983, Sammarco et al. 1983). The lower number of coral recruits observed around these soft corals thus appears to be the result of inhibition through allelopathic interference. Analyses using the allelopathic response index proposed by Williamson \& Richardson (1988) also supported this assumption.
The laboratory-based settlement inhibition study demonstrated that extracts containing secondary metabolites from Sinularia flexibilis inhibit recruitment of scleractinian coral spat (see also Maida 1993). The inhibition of recruitment of coral larvae on plates impregnated with an extract of $S$. flexibilis is consistent with our finding of inhibition of coral recruitment around soft corals in the field. We believe this is attributable to the allelopathic effects of toxic secondary metabolites from the soft coral.

The low settlement rate of coral larvae (18/3500) observed in the laboratory experiment may have been due to the use of primary (unseasoned) settlement substrata. It is known that for some marine larvae, a new settlement substratum requires a period of preparation (initial benthic community succession) before settlement of certain marine larvae will occur. This frequently includes the formation of a primary bacterial surface film, followed by diatom colonization, and then the settlement of invertebrate larvae and other microalgae (Wahl 1989). Unfortunately, because the treated settlement plates were impregnated with soft coral extract, it was not possible to precondition any of the plates

In the field experiments, inhibition of coral recruitment had a directional component which was correlated with the direction of the prevailing currents. The currents at Orpheus Island flowed predominantly towards the west, and at Lizard Island, towards the north. At both sites, the lowest levels of coral recruitment occurred on the plates downcurrent from the soft corals. Hydrodynamic theory regarding particle entrainment would predict concentration of larvae in the lee of an obstruction to the flow (Mullineaux \& Butman 1991, Mullineaux \& Garland 1993; see also Black \& Gay 1987, Andrews et al. 1988, Sammarco \& Andrews 1988, 1989, Gay \& Andrews 1994), the opposite of what was observed here. Inhibition of coral recruitment was generally stronger on substrata closer to the soft corals.

Three explanatory hypotheses have been offered to explain the significant negative correlation observed between coral spat density and current flow: (1) that the larvae may sense the presence of the soft coral chemicals and avoid the area (sensu Gauthier \& Aubert 1981); (2) that the larvae sense allelochemicals adsorbed onto the substratum and exercise a negative preference, re-entering the water column; or (3) that the larvae settle and die, due to the allelochemicals, prior to the secretion of a calcium carbonate skeleton, leaving no trace of their presence. It is still not known which of these mechanisms is operating. Additional laboratory experiments are needed to distinguish amongst these hypotheses.

It is certainly possible that the lower density of coral recruits around the soft corals may have been caused 
by an avoidance response in the coral larvae (sensu Keough \& Downes 1982; see also Pawlik 1992). Detection of the presence of a soft coral is possible for coral planulae, since most coelenterate larvae have specialized chemical sensory apparatus that could detect allelochemicals in the water (see Chia \& Bickell 1978). As the coral larvae enter the vicinity of the soft coral, they may sense the soft coral allelochemicals either in the water column or on the substratum, avoid the area, and resume their search for a suitable settlement site. This remains to be confirmed.

The results reported here confirm the findings of an earlier experiment (Maida et al. 1995) and provide new evidence that alcyonacean soft corals can influence the recruitment of scleractinian corals on nearby substrata through allelopathic interference.

Acknowledgements. We thank Beatrice P. Ferreira for her invaluable assistance in the field and comments throughout the study and on the manuscript. We are also grateful to $\mathrm{M}$. Becerro, R. de Nys, K. Fabricius, P. Spratt, P. Stephenson, C. Wilkinson, D. Zeller and many others who assisted in the field. We thank G. Charles, S. Charles (Orpheus Island Research Station), L. Vail, A. Hoggett, M. \& L. Pearce (Lizard Island Research Station) for the logistic support and assistance at the research stations. Many thanks to R. Babcock for supplying the coral larvae for the lab experiments. We are also grateful to A. R. Carroll for comments throughout the work. This study was supported by the Australian Research Council and CAPES (Brazilian Education Ministry). The manuscript benefited from suggestions made by Steve McKillup.

\section{LITERATURE CITED}

Andrews JC, Gay S, Sammarco PW (1988) Influence of circulation on self-seeding patterns at Helix Reef - Great Barrier Reef. Proc 6th int Coral Reef Symp 2:469-474

Babcock RC (1988) Fine-scale spatial and temporal patterns in coral settlement. Proc 6th int Coral Reef Symp 2: $635-639$

Babcock RC, Bull G, Harrison PL, Heyward AJ, Oliver JK, Willis BL (1986) Synchronous spawning of 105 scleractinian coral species on the Great Barrier Reef. Mar Biol 90: 379-394

Babcock RC, Heyward AJ (1986) Larval development of certain gamete-spawning scleractinian corals. Coral Reefs 5: $111-116$

Bak. RPM, Engel MS (1979) Distribution, abundance and survival of juvenile hermatypic corals (Scleractinia) and the importance of life history strategies in the parent coral community. Mar Biol 54:341-352

Bakus GJ, Schulte G, Targett NM (1986) Chemical ecology of marine organisms: an overview. J chem Ecol 12:951-987

Birkeland C (1977) The importance of rate of biomass accumulation in early successional stages of benthic communities to the survival of coral recruits. Proc $3 r d$ int Coral Reef Symp 1:15-21

Black KP, Gay SL (1987) Eddy formation in unsteady flows. J geophys Res 92:9514--9522

Bowden BF, Coll JC, Tapiolas DM, Willis R (1985) Some chemical aspects of spawning in alcyonacean corals. Proc 5 th int Coral Reef Congr 4:325-329
Carleton JC, Sammarco PW (1987) Effects of substratum irregularity on success of coral settlement: quantification by comparative geomorphological techniques. Bull mar Sci 40:85-98

Chia F, Bickell LR (1978) Mechanisms of larval attachment and the induction of settlement and metamorphosis in coelenterates: a review. In: Chia F, Rice ME (eds) Settlement and metamorphosis of marine invertebrate larvae. Elsevier, New York, p 1-12

Coll JC (1992) The chemistry and chemical ecology of octocorals (Coelenterata, Octocorallia). Chem Rev 92: 613-631

Coll JC, Bowden BF, Tapiolas DM, Dunlap WC (1982a) In situ isolation of allelochemicals from soft corals (Coelenterata: Octocorallia): a totally submersible sampling apparatus. $\mathrm{J}$ exp mar Biol Ecol 60:293-299

Coll JC, La Barre SC, Sammarco PW, Williams WT, Bakus GJ (1982b) Chemical defenses in soft corals (Coelenterata Octocorallia) of the Great Barrier Reef: a study of comparative toxicities. Mar Ecol Prog Ser 8:271-278

Coll JC, Miller RL (1992) Nature of sperm chemoattractants in coral and starfish. In: Baccetti, B (ed) Comparative spermatology. Raven Press, New York, p 129-134

Coll, JC, Price, IR, König, GM, Bowden, BF (1987) Algal overgrowth of alcyonacean soft corals. Mar Biol 96:129-135

Coll JC, Sammarco PW (1983) Terpenoid toxins of soft corals (Cnidaria: Octocorallia): their nature, toxicity and their ecological significance. Toxıcon Suppl 3:69-72

Dai CF (1990) Interspecific competition in Taiwanese corals with special reference to interactions between alcyonaceans and scleractinians. Mar Ecol Prog Ser 60:291-297

Faulkner DJ (1991) Marine natural products. Nat Prod Rep 8:97-147

Fisk DA, Harriott VJ (1990) Spatial and temporal variation in coral recruitment on the Great Barrier Reef: implications for dispersal hypothesis. Mar Biol 107:485-490

Fitzhardinge RC (1985) Spatial and temporal variability in coral recruitment in Kaneohe Bay (Oahu, Hawaii). Proc 5th int Coral Reef Symp 4:373-378

Fitzhardinge RC (1988) Coral recruitment: the importance of interspecific differences in juvenile growth and mortality. Proc 6th int Coral Reef Symp 2:673-678

Gauthier MJ, Aubert M (1981) Chemical telemediators in the marine environment. In: Duursma EK, Dawson R (eds) Marine organic chemistry: evolution, composition, interactions and chemistry of organic matter in seawater. Elsevier Oceanography Series, Vol 31. Elsevier, Amsterdam, p 225-249

Gay SL, Andrews JC (1994) The effects of recruitment strategies on coral larvae settlement distributions at Helix Reef. In: Sammarco PW, Heron ML (eds) The bio-physics of marine larval dispersal. American Geophysical Union, Washington, DC, p 73-88

Harriott VJ (1985) Recruitment patterns of scleractinian corals at Lizard Island, Great Barrier Reef. Proc 5th int Coral Reef Congr $4: 367-372$

Harriott VJ, Fisk DA (1987) A comparison of settlement plate types for experiments on the recruitment of scleractinian corals. Mar Ecol Prog Ser 37:201-208

Harrison PL, Babcock RC, Bull GD, Oliver JK, Wallace CC, Willis BL (1984) Mass spawning in tropical reef corals. Science 223:1186-1189

Harvell CD, Fenical W, Roussis V, Ruesink JL, Griggs CC, Greene $\mathrm{CH}$ (1993) Local and geographic variation in the defensive chemistry of a West Indian gorgonian coral (Briareum asbestinum). Mar Ecol Prog Ser 93:165-173

Hodgson G (1990) Sediment and the settlement of larvae of the reef coral Pocillopora damicornis. Coral Reefs 9:41-43 
Hughes TP (1.985) Life histories and population dynamics of early successional corals. Proc 5th int Coral Reef Symp 4 $104-106$

Hughes TP, Jackson JBC (1985) Population dynamics and life histories of foliaceous corals. Ecol Monogr 55:141-166

Keough MJ, Downes BJ (1982) Recruitment of marine invertebrates: the role of active larval choice and early mortality. Oecologia 45:348-352

La Barre SC, Coll JC, Sammarco PW (1986a) Competitive strategies of soft corals III: spacing and aggressive interactions between alcyonaceans. Mar Biol 28:147-156

La Barre SC, Coll JC, Sammarco PW (1986b) Defensive strategies of soft corals (Coelenterata: Octocorallia) of the Great Barrier Reef II. The relationship between toxicity and feeding deterrence. Biol Bull 171:565-576

Levins RA (1968) Evolution in changing environments Princeton University Press, Princeton, NJ

Maida M (1993) Allelopathic effects of alcyonacean soft corals on the settlement and early development of scleractinian corals. PhD thesis, James Cook University of North Queensland, Townsville

Maida M, Coll JC, Sammarco PW (1993) A simple current direction meter and its applicability to marine ecological studies. J exp mar Biol Ecol 174:115-119

Maida M, Coll JC, Sammarco PW (1994) Shedding new light on scleractinian coral recruitment. J exp mar Biol Ecol 180: 189-202

Maida M, Sammarco PW, Coll JC (1995) Directional allelopathic effects of the soft coral Sinularia flexibilis (Alcyonacea: Octocorallia) on scleractinian coral recruitment. Bull mar Sci 56:303-311

Morse DE, Morse ANC (1992) Sulfated polysaccharide induces settlement and metamorphosis of Agaricia humilis larvae on specific crustose algae. Proc 7th int Coral Reef Symp 1:502

Mullineaux LS, Butman CA (1991) Initial contact, exploration and attachment of barnacle (Balanus amphitrite) cyprids settling in. flow. Mar Biol 1.10:93-103

Mullineaux LS, Garland ED (1993) Larval recruitment in response to manipulated field flows. Mar Biol 116: $667-683$

Pawlik JR (1992) Chemical ecology of the settlement of benthic marine invertebrates. Oceanogr mar Biol A Rev 30: 273-335

Rinkevich B, Loya Y (1979) The reproduction of the Red Sea coral Stylophora pistillata. II. Synchronization in breeding and seasonality of planulae shedding. Mar Ecol Prog Ser 1:145-152

Sammarco PW (1980) Diadema and its relationship to coral spat mortality: grazing, competition, and biological disturbance. J exp mar Biol Ecol 45:245-272

Sammarco PW (1982) Echinoid grazing as a structuring force in coral communities: whole reef manipulations. J exp mar Biol Ecol 61:31-55

Sammarco PW (1983) Coral recruitment across the central Great Barrier Reef: a preliminary report. In: Baker JT, Carter R, Sammarco PW, Stark KP (eds) Proc Great Barrier Reef Conf. James Cook University Press, Townsville, p $245-251$

Sammarco PW (1985) The Great Barrier Reef vs the Caribbean: comparisons of grazers, coral recruitment patterns, and reef recovery. Proc 5th int Coral Reef Congr 4: 391-397

Sammarco PW (1987) A comparison of ecological processes on coral reefs of the Caribbean and the Great Barrier Reef.
In: Birkeland C (ed) Comparison between Atlantic and Pacific tropical marine coastal ecosystems: community structure, ecological processes, and productivity. University of the South Pacific, Fiji, 1986. UNESCO Rep mar Sci 46: $127-166$

Sammarco PW (1991) Geographically specific recruitment and post-settlement mortality as influences on coral communities: the cross-continental shelf transplant experiment. Limnol Oceanogr 36:496-514

Sammarco PW (1994) Larval dispersal and recruitment processes in corals: analysis and synthesis. In: Sammarco PW, Heron ML (eds) The bio-physics of marine larval dispersal. American Geophysical Union, Washington, DC, p 35-72

Sammarco PW, Andrews JC (1988) Localized dispersal and recruitment in Great Barrier Reef corals: the Helix experiment. Science 239:1422-1424

Sammarco PW, Andrews JC (1989) The Helix Experiment: differential local recruitment patterns in Great Barrier Reef corals. Limnol Oceanogr 34:898-914

Sammarco PW, Coll JC (1988) The chemical ecology of alcyonarian corals (Coelenterata: Octocorallia). In: Scheuer PJ (ed) Bioorganic marine chemistry, Vol 2. Springer Verlag, Berlin, p $87-116$

Sammarco PW, Coll JC, La Barre SC, Willis BL (1983) Competitive strategies of soft corals (Coelenterata: Octocorallia): allelopathic effects on selected scleractinian corals Coral Reefs 1:173-178

Shlesinger Y, Loya Y (1985) Coral community reproductive patterns: Red Sea versus the Great Barrier Reef. Science 228:1333-1335

Sokal RR, Rohlf FJ (1.981) Biometry, 2nd edn. Freeman, San Francisco

Szmant AM (1991) Sexual reproduction by the Caribbean reef corals Montastrea annularis and $M$. cavernosa. Mar Ecol Prog Ser 74:13-25

Tursch B, Braekman JC, Daloze D, Kaisin M (1978) Terpenoids from coelenterates. In: Scheuer PJ (ed) Marine natural products: chemical and biological perspectives, Vol 2. Academic Press, New York, p 247-296

Van Alstyne KL, Paul VJ (1992) Chemical and structural defenses in the sea fan Gorgonia ventalina: effects against generalist and specialist predators. Coral Reefs 11. $155-159$

Vine PJ (1974) Effects of algal grazing and aggressive behavior of fishes Pomacentrus lividus and Acanthurus sohal on coral reef ecology. Mar Biol 24:131-136

Wahl M (1989) Marine epibiosis. I. Fouling and antifouling some basic aspects. Mar Ecol Prog Ser 58:175-189

Wallace CC (1985) Seasonal peaks and annual fluctuation in recruitment of juvenile scleractinian corals. Mar Ecol Prog Ser 21:289-298

Williamson GB, Richardson D (1988) Bioassays for allelopathy: measuring treatment responses with independent controls. J chem Ecol 14:181-188

Willis BL, Babcock RC, Harrison PL, Oliver JK, Wallace CC (1985) Patterns in the mass spawning of corals on the Great Barrier Reef from 1981-1984. Proc 5th int Coral Reef Congr 4:113-11.7

Wylie CR, Paul VJ (1989) Chemical defences in three species of Sinularia (Coelenterata, Alcyonacea): effects against generalist predators and the butterflyfish Chaetodon unimaculatus Bloch. J exp mar Biol Ecol 129:141-160

Zar JH (1984) Biostatistical analysis, 2nd edn. Prentice-Hall International, Englewood Cliffs, NJ

Manuscript first received: January 28, 1994

Revised version accepted: January 24, 1995 